\title{
Biological functions and receptor binding activities of equine chorionic gonadotrophins
}

\author{
Francesca Stewart* and W. R. Allen \\ T.B.A. Equine Fertility Unit, A.R.C. Institute of Animal Physiology, Animal Research Station, \\ 307 Huntingdon Road, Cambridge CB3 OJQ, U.K.
}

\begin{abstract}
Summary. The role of equine chorionic gonadotrophin (CG, formerly termed Pregnant Mare Serum Gonadotrophin, PMSG) in maintaining equine pregnancy was investigated by examining the effects of this hormone on the maternal ovaries during early gestation and relating these findings to the receptor binding activities of $\mathrm{CG}$ in vitro. Measurement of plasma progestagen profiles in mares and donkeys carrying horse, donkey, mule ( $q$ horse $\times \delta^{\star}$ donkey) and hinny ( $q$ donkey $\times \delta^{\star}$ horse) conceptuses confirmed that $C G$ induced several secondary ovulations and thus maintained maternal progestagen concentrations. However, in mares carrying horse and mule conceptuses and in donkeys carrying donkey conceptuses the growth of the follicles that gave rise to the secondary corpora lutea occurred before $\mathrm{CG}$ was secreted and the CG did not express any FSH-like activity. Nevertheless, in donkeys carrying hinny pregnancies the CG secreted by the hinny conceptus stimulated massive follicular growth in addition to luteinization, presumably because of an enhanced sensitivity of donkey ovaries to hinny CG which, as demonstrated in previous studies, is a mixture of horse and donkey $\mathrm{CG}$ and hence has considerably more FSH-like activity than normal donkey CG.

In-vitro receptor binding experiments showed that both horse and donkey gonadal tissues possessed a low binding affinity for horse CG compared to that exhibited by equivalent gonadal tissues of other species. Furthermore, horse CG bound with low, but significant, affinity to horse and donkey $\mathrm{LH}$ receptors and donkey FSH receptors, but exhibited negligible binding to horse FSH receptors.

We suggest that in equids the receptor-mediated refractoriness to the gonadotrophic activities of the intraspecific chorionic gonadotrophin protects the ovaries during pregnancy.
\end{abstract}

\section{Introduction}

It is now well established that the gonadotrophin which is present in high concentration in the blood of mares during early pregnancy (pregnant mares' serum gonadotrophin: PMSG) is chorionic in origin (Allen \& Moor, 1972; Allen, Hamilton \& Moor, 1973) and that donkey, zebra and horse $x$ donkey hybrid (mule and hinny) conceptuses secrete a similar hormone (Calisti \& Oliva, 1956; King, 1965; Allen, 1969a). We therefore propose that these hormones be referred to as chorionic gonadotrophins $(\mathrm{CG})$ and we use this terminology in the present paper.

Studies involving bilateral ovariectomy in pregnant mares (Holtan, Squires, Lapin \& Ginther, 1979) and measurement of progesterone concentrations in placental tissues (Short, 1959) have indicated that the equine placenta does not begin to secrete appreciable quantities of

* Present address: CSIRO Division of Wildlife Research, P.O. Box 84, Lyneham, A.C.T. 2602, Australia. 
progesterone until after Day 80 of gestation. Before this, pregnancy is maintained by progesterone secreted by both the primary corpus luteum and one or more secondary corpora lutea which develop in the maternal ovaries from around Day 40 (Amoroso, Hancock \& Rowlands, 1948; van Niekerk, 1973; Squires \& Ginther, 1975). The coincidental development of secondary corpora lutea with the commencement of secretion of horse CG at Day 40 , together with the fact that this hormone expresses both follicle-stimulating hormone (FSH) and luteinizing hormone (LH) biological activities (Cole, 1936; Papkoff, 1974), has led to the general hypothesis that horse CG stimulates the growth of accessory follicles and causes their ovulation or luteinization to form the secondary corpora lutea. However, Bain (1967), van Rensburg \& van Niekerk (1968) and others have reported considerable follicular growth in pregnant mares between Days 17 and 30 which is well before the first secretion of horse CG. Also, Evans \& Irvine (1975), Stewart (1978) and Allen, Stewart \& Urwin (1980) have demonstrated that the wave-like increases in plasma FSH concentrations which occur at approximately 10-12-day intervals in the cyclic mare continue unchanged during early pregnancy. These findings, together with our recent observation that horse CG has an extremely low binding affinity for horse gonadal FSH and LH receptors (Stewart \& Allen, 1979), suggest that pituitary FSH rather than horse CG stimulates the accessory follicular growth that occurs during early pregnancy.

The apparent lack of gonadotrophic activity of endogenous CG is also demonstrated by the fact that, despite the major differences in maternal serum CG concentrations which occur between horses and donkeys carrying horse, mule or donkey conceptuses (Allen, 1969a), ovarian activity, as evidenced by peripheral plasma progesterone concentrations, does not differ significantly between them. The donkey carrying a hinny conceptus forms a notable exception to the other three types of equine pregnancy, however, and in these animals, in which CG levels are 5-8-fold higher than in donkeys carrying donkey conceptuses, ovarian progesterone secretion rate is enormously increased with peripheral plasma concentrations reaching as high as 600 $\mathrm{ng} / \mathrm{ml}$ (Allen, 1975; Sheldrick, Wright, Allen \& Heap, 1977).

In the present study we have further examined the gonadotrophic activity of equine CGs in equine pregnancy by comparing the relationship between gonadotrophin levels and ovarian activity in horse, donkey, mule and hinny pregnancies to the ratio of FSH-like to LH-like activities of the CG secreted by each type of conceptus. We have also investigated the binding of horse CG to donkey gonadal FSH and LH receptors.

\section{Materials and Methods}

\section{Animals}

Over a 3-year period serial plasma and serum samples were collected at approximately weekly intervals between the 1st and 24th weeks of gestation from a total of 30 Pony mares carrying normal horse conceptuses, 14 jenny donkeys carrying normal donkey conceptuses, 11 mares carrying mule conceptuses and 6 donkeys carrying hinny conceptuses. The samples were stored at $-20^{\circ} \mathrm{C}$ until assayed for steroid and gonadotrophin concentrations as described below.

The ovaries of 5 mature donkeys of unknown breeding history were collected within 15 min after death at a slaughterhouse and the ovary containing the ovulatory follicle was recovered at laparotomy from one donkey in mid-oestrus. In addition the testes of a 9-month-old donkey were removed under general anaesthesia. The organs were placed on crushed ice, the tunica albuginea removed, and the follicles, corpora lutea and pieces of testicular parenchyma dissected free and prepared for receptor studies as described below.

Ovarian activity was assessed during laparotomy under general anaesthesia, at slaughter, or by rectal palpation, at various stages of gestation in several animals carrying horse, donkey, mule and hinny conceptuses. Gestational ages were calculated from known ovulation dates or by fetal weight (Allen, 1970). 


\section{Tissue preparation}

Testicular and corpus luteum tissues were chopped finely in an approximately equal volume of assay buffer (10 mM-sodium phosphate buffer, $\mathrm{pH} 7.4$, with $0.1 \mathrm{M}$-sucrose, $5 \mathrm{mM}$ - $\mathrm{MgCl}_{2}$, $0.1 \% \mathrm{BSA}$ ) at $4^{\circ} \mathrm{C}$, homogenized in a hand-held glass homogenizer, filtered through 2 layers of butter muslin and centrifuged at $2000 \mathrm{~g}$ for $15 \mathrm{~min}$. The tissue pellet was weighed, diluted to a concentration of $100 \mathrm{mg} / \mathrm{ml}$ assay buffer and stored at $-20^{\circ} \mathrm{C}$ in $2-\mathrm{ml}$ aliquots for receptor measurements and in 20-ml aliquots for competitive binding studies. Follicles were cut open under assay buffer at $4^{\circ} \mathrm{C}$ and scraped with a scalpel blade to remove the granulosa and theca interna cells. All follicles $>1 \mathrm{~cm}$ in diameter were pooled for competitive binding studies and, after receptor measurements had been made on a portion of the individual 'oestrous' follicles, the remainder of these were also added to the pooled material. The resulting cell suspensions were homogenized by hand if necessary and filtered, washed, diluted and stored as described for the testes and corpora lutea.

\section{Hormones}

Highly purified human LH (DEAE-I, 27/1/69; $2.83 \mathrm{mg} \mathrm{NIH-LH-S1/mg;} \mathrm{Stockell-Hartree,}$ 1966), human FSH (LER 1575c; $144 \mathrm{mg} \mathrm{NIH-FSH-S1/mg;} \mathrm{Reichert,} \mathrm{1972)} \mathrm{and} \mathrm{horse} \mathrm{CG}$ (PMSG-PM-19B; 2.0 mg NIH-LH-S1/mg; $105 \mathrm{mg}$ NIH-FSH-S1/mg; Schams \& Papkoff, 1972) were used for radioiodination throughout and as reference preparations in the competitive binding studies. Highly purified equine LH and FSH (E98A and E99B; Licht et al., 1979) were used to test specificity and cross-reactivity in the binding studies.

\section{Radioiodination}

Highly purified LH (DEAE-I) and horse CG (PM-19B) were iodinated by a 'mild' chloramine-T method (Stewart, Allen \& Moor, 1976). The FSH (LER 1575c) was iodinated enzymically using the lactoperoxidase method described by Cheng (1975) except that approximately one-tenth the amount of enzyme, half the amount of $\mathrm{H}_{2} \mathrm{O}_{2}$ and one-third of the reaction time were used. Care was taken to ensure that the specific activities of the labelled $\mathrm{LH}$, FSH and horse CG were similar and within the range of $9-14 \mu \mathrm{Ci} / \mu \mathrm{g}$.

Assays

Immunoassay of equine CGs. Serum equine $\mathrm{CG}$ concentrations were measured by haemagglutination-inhibition assay as described by Allen (1969b) using a rabbit anti-horse CG serum (R260c) raised against highly purified horse CG (Ge27R2, 14500 i.u./mg; Organon Ltd, Oss, Holland). The Second International Standard of Mare Serum Gonadotrophin (2nd IS-PMSG; Bangham \& Woodward, 1966) was used as standard and the limit of sensitivity of the assay was $0.5 \mathrm{i} . \mathrm{u} . / \mathrm{ml}$ serum.

Progestagen assay. Progestagen concentrations were measured in a competitive proteinbinding assay based on the method developed for corticosteroids by Bassett \& Hinks (1969). Sephadex-stripped dog plasma was used as the source of steroid-binding globulin (SBG) and $\left[1,2,6,7-{ }^{3} \mathrm{H}\right]$ cortisol (Radiochemical Centre, Amersham, Bucks) as label. Plasma samples $(0 \cdot 2$ $\mathrm{ml}$ aliquots) were heated at $60^{\circ} \mathrm{C}$ for $10 \mathrm{~min}$, cooled, and then extracted with 20 volumes of petroleum ether (40:60 BP, British Drug Houses, Sussex) before assay. This extraction step provided specificity in the assay and avoided the necessity of having to use chromatographic methods to isolate progesterone. Johansson (1970) demonstrated that petroleum ether extracts around $90 \%$ of progesterone from plasma but only very small amounts of other, potentially cross-reacting steroids such as cortisol and oestrogens. However, this solvent does also extract some metabolites of progesterone and we therefore refer to progestagen, rather than 
progesterone, concentrations throughout this paper. Free and SBG-bound fractions were separated on small Sephadex G-25 columns.

The limit of sensitivity of the assay was $0.2 \mathrm{ng} / \mathrm{ml}$ plasma and the intra- and interassay coefficients of variation 10.2 and $12.5 \%$ respectively.

Receptor binding measurements. Receptor binding activities were measured as described previously (Stewart \& Allen, 1979) using $200 \mu$ laliquots ( $\Omega 20 \mathrm{mg}$ wet tissue) of tissue suspension and approximately 40000 c.p.m. ${ }^{125}$ I-labelled FSH and ${ }^{125}$ I-labelled LH or 80000 c.p.m. ${ }^{125}$ I-labelled horse CG. The larger amount of labelled horse CG was used to compensate for the fact that its molecular weight $(60000$; Gospodarowicz, 1972) is approximately twice that of FSH and LH. Initially, measurements were made with the labelled FSH, LH and horse CG added to several tissue concentrations. This was done to ensure that sufficient label was being added to saturate all available binding sites. However, in some cases the binding affinity of horse CG was so low that in view of the limited supply of highly purified horse CG available it was not practical to test for complete saturation. However, in these instances the reduction in binding was of at least an order of magnitude, and so any possible errors involved could not have had a significant effect on the overall result. Also, the percentage binding never exceeded $10 \%$ of the hormone added which gave a further indication of complete saturation. Incubations were carried out at $37^{\circ} \mathrm{C}$ for $14-16 \mathrm{~h}$ and non-specific binding was determined by the addition of excess unlabelled LH (10 $\mu$ g NIH-LH-S6), FSH (10 $\mu$ g NIH-FSH-P1) or horse CG (50 i.u. Folligon: Intervet Laboratories, Cambridge) to the assay tubes. Measurements were performed in duplicate for each tissue sample, using two tissue concentrations and repeated at least twice in separate assays. Two aliquots of tissue suspension were also assayed for DNA content as described below and the results expressed as $\mu \mathrm{mol}$ hormone specifically bound/ $\mu \mathrm{g}$ DNA.

DNA assay. Samples of tissue suspensions were digested in $0.5 \mathrm{~N}$-perchloric acid at $70^{\circ} \mathrm{C}$ for $30 \mathrm{~min}$, diluted to $1 \mathrm{ml}$ with $0.5 \mathrm{~N}$-perchloric acid, centrifuged at $1000 \mathrm{~g}$ for $5 \mathrm{~min}$ and $0.8 \mathrm{ml}$ of the supernatant was assayed for DNA by the standard colorimetric method described by Burton (1956).

Competitive binding studies. The relative binding affinities of the FSH-like and LH-like activities of horse CG to donkey FSH and LH receptors were measured by the techniques described previously for horse gonadotrophin receptors (Stewart \& Allen, 1979). Because of the dual binding activities of horse CG, and because both types of receptor were present in the tissues being assayed, it was necessary to saturate, with excess unlabelled hormone, the FSH receptors when measuring $\mathrm{LH}$ receptor binding affinity and the LH receptors when measuring FSH receptor binding affinity (see Stewart et al., 1976; Stewart \& Allen, 1979). Also, since the initial binding of ${ }^{125}$ I-labelled FSH to both horse and donkey testis tissue was low and the non-specific binding relatively high, a receptor-rich fraction was prepared for these tissues. This was done by homogenizing the tissue in $25 \mathrm{~mm}$-Tris- $\mathrm{HCl}$ buffer with $0.3 \mathrm{M}$-sucrose, $\mathrm{pH} 7.4$, centrifuging the suspension at $15000 \mathrm{~g}$ for $30 \mathrm{~min}$, discarding the tissue pellet and centrifuging the supernatant at $100000 \mathrm{~g}$ for $90 \mathrm{~min}$. The resulting pellet was resuspended in assay buffer at a concentration of $100 \mathrm{mg} / \mathrm{ml}$.

Dose-response curves were constructed for the human and equine hormones using the different tissues and the binding capacity of each hormone was expressed as the amount required to displace $50 \%$ of the total ${ }^{125}$ I-labelled FSH or $\mathrm{LH}$ bound to the tissue in the absence of unlabelled hormone. Subsequently, the relative binding affinity of horse CG for the different receptors was expressed as a percentage of that shown by equine pituitary FSH and LH.

\section{Results}

Gonadotrophin and progestagen levels in pregnant equids

The mean plasma progestagen and serum chorionic gonadotrophin concentrations measured 
are shown in Text-fig. 1. In agreement with the previous findings of Allen (1969a), fetal genotype exerted a marked effect on CG production; concentrations were high in mares carrying horse conceptuses and donkeys carrying hinny conceptuses, but much lower in mares carrying mule conceptuses and donkeys carrying normal donkey conceptuses.

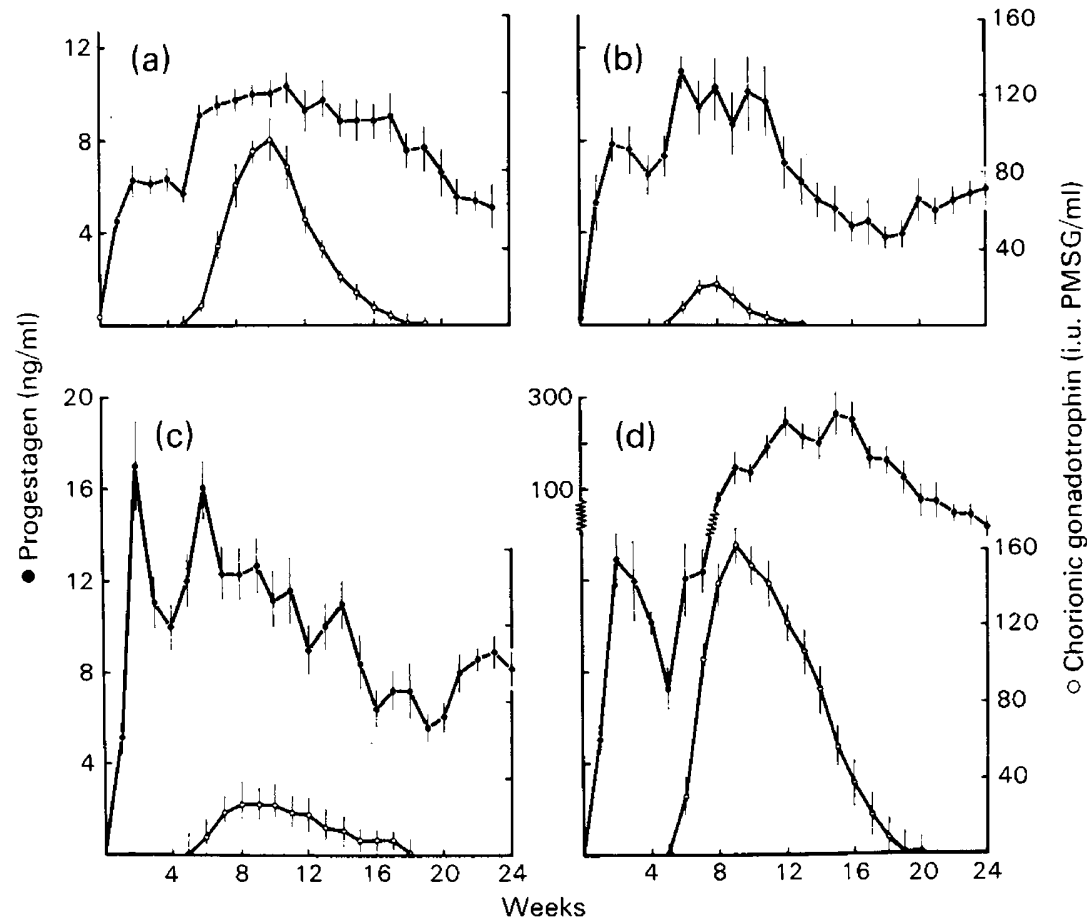

Text-fig. 1. Mean ( \pm s.e.m.) plasma progestagen (O) and serum CG (O) concentrations measured at weekly intervals in the blood of (a) 30 pregnant Pony mares carrying normal horse conceptuses; (b) 11 mares carrying mule conceptuses; (c) 14 donkeys carrying normal donkey conceptuses; and (d) 6 donkeys carrying hinny conceptuses.

In all four types of pregnancy, plasma progestagen concentrations increased rapidly after ovulation (Day 0) to a peak in the second week of gestation. This represented maximum secretory activity of the primary corpus luteum and the fact that the peak was higher in donkeys (12-16 ng/ml plasma; Text-figs $1 \mathrm{c}$ and $1 \mathrm{~d})$ than mares (6-8 $\mathrm{ng} / \mathrm{ml}$ plasma; Text-figs $1 \mathrm{a}$ and $1 \mathrm{~b})$, irrespective of the genotype of the fetus being carried, probably reflected the dilution effect of the greater blood volume in the larger mares. Levels declined steadily between Weeks 2 and 5 in all types of pregnancy but then rose again sharply between Weeks 5 and 6 , indicating the occurrence of the first secondary ovulation in conjunction with the start of CG secretion. In the mares carrying normal horse conceptuses (Text-fig. 1a), progestagen levels then remained elevated for several weeks and only began to decline around Week 18 when CG concentrations had become very low. In the mares carrying mule conceptuses, where CG concentrations were much lower and reached baseline much earlier in pregnancy (Text-fig. 1b), the decline in progestagen levels also began much earlier in pregnancy, around Week 11 . The further slight rise which started around Week 20 presumably reflected increasing placental progesterone secretion.

An earlier decline in progestagen levels from around Week 14, followed by a further rise at Week 20, was also seen in the donkeys carrying donkey conceptuses (Text-fig. 1c). However, in marked contrast to the other three pregnancy types, the progestagen levels in the donkeys carrying hinny conceptuses rose very steeply after Week 7 to reach extremely high 
concentrations (100-300 $\mathrm{ng} / \mathrm{ml}$ plasma) by Week 9 . Concentrations began to decline again around Week 17 but they nevertheless remained considerably higher than those in the other three pregnancy genotypes until term (Text-fig. 1d).

Since the elevation in progestagen levels which occurred between Weeks 6 and 17 of gestation in the horse and hinny pregnancies, and Weeks 6 and 11 in the mule and donkey pregnancies, was considered to provide a valid measure of the degree of maternal ovarian response to $\mathrm{CG}$ in each type of pregnancy, progestagen concentrations during this period were averaged and compared to the mean peak CG concentrations (Table 1). These comparisons clearly demonstrated that, despite major differences in mean peak CG concentrations between the horse, mule and donkey pregnancies $(112.6,26.4$ and $27.4 \mathrm{i} . \mathrm{u} . / \mathrm{ml}$ respectively), there was no difference between their mean plasma progestagen concentrations $(9.7,9.8$ and $12.2 \mathrm{ng} / \mathrm{ml}$ respectively). Furthermore, a regression analysis of progestagen versus CG concentrations measured in 15 mares carrying normal horse conceptuses also failed to show any correlation $(r$ $=0.18$ ) between levels of the two hormones within this single pregnancy genotype. In the donkeys carrying hinny conceptuses, on the other hand, while the mean peak CG concentration $(161.4 \mathrm{i} . \mathrm{u} . / \mathrm{ml})$ was only 1.4 times higher than that in mares carrying horse conceptuses $(112.6$ i.u. $/ \mathrm{ml})$, the mean plasma progestagen concentration $(160.0 \mathrm{ng} / \mathrm{ml})$ was 16 -fold higher than progestagen levels in the horse and the other two pregnancy genotypes.

Table 1. Mean \pm s.e.m. concentrations of $C G$ and progestagen in pregnant equids

\begin{tabular}{ccccc}
\hline & \multicolumn{4}{c}{ Conceptus } \\
\cline { 2 - 5 } & Horse & Mule & Donkey & Hinny \\
\hline $\begin{array}{c}\text { Peak CG conc. } \\
\text { (i.u./ml serum) }\end{array}$ & $112.6 \pm 17.4$ & $26.4 \pm 5.9$ & $27.4 \pm 5.9$ & $161.4 \pm 14.7$ \\
$\begin{array}{c}\text { Progestagen conc. } \\
\text { (ng/ml plasma) }\end{array}$ & $9.7 \pm 0.54^{*}$ & $9.8 \pm 1.2 \ddagger$ & $12.2 \pm 0.95 \ddagger$ & $160.0 \pm 21.9^{*}$ \\
\hline
\end{tabular}

For *Weeks 6-17 and $\ddagger$ Weeks $6-11$ of pregnancy.

\section{Ovarian development during early pregnancy}

Considerable follicular activity was observed before the production of CG and seemed greatest between Days 25 and 30 in all the pregnant horses and donkeys examined. But around Day 60, when CG levels were reaching their peak, a marked difference was evident between the horse, donkey and mule pregnancies on the one hand and the hinny pregnancies on the other. In the former group the ovaries showed less follicular activity than at Day 30 and they contained only 2 or 3 corpora lutea of normal size and, sometimes, a luteinized follicle (Plate $1 \mathrm{~b}$ ). In the donkeys carrying hinny conceptuses, both ovaries were greatly enlarged and they were packed with many abnormally large follicles, corpora lutea and luteinized follicles (Plate 1a). These observations correlated well with the plasma progestagen levels measured in the 4 types of pregnancy (Text-fig. 1 and Table 1) and they also supported the previous observation of Sheldrick et al. (1977) that the very high level of progesterone in the blood of donkeys carrying hinny conceptuses is ovarian in origin.

We showed previously that hinny CG possesses considerably more FSH-like activity than aes normal donkey CG and is probably a mixture of horse and donkey CG (Stewart, Allen \& iNoor, 1977). This led us to suggest that the ovarian activity seen in donkeys carrying hinny conceptuses may be stimulated by the 'horse' component of hinny CG which has a higher FSH activity than the CG to which the donkey is normally exposed during intraspecific pregnancy. To test this hypothesis, we compared the binding of horse CG to donkey and horse gonadal receptors. 


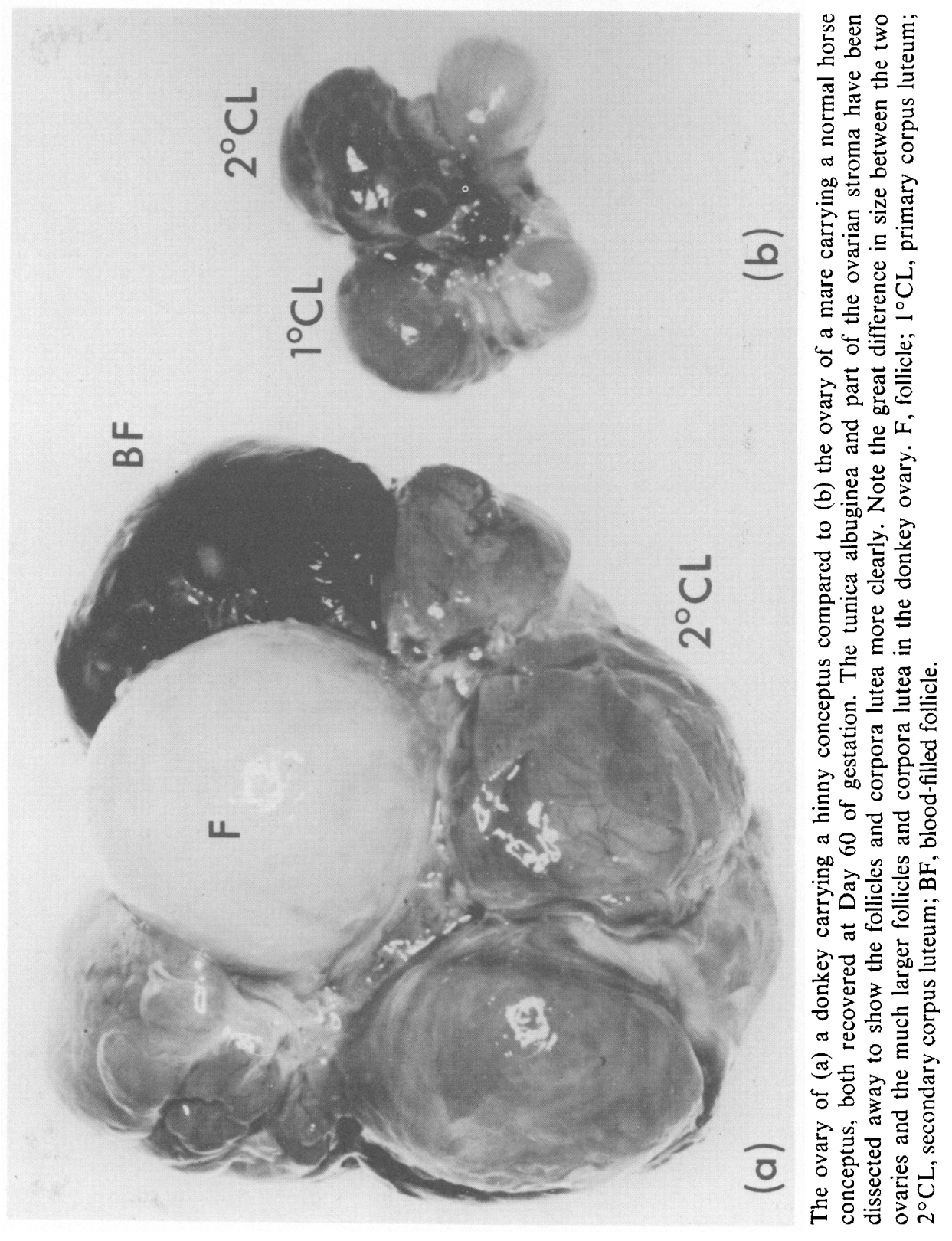

(Facing p. 532) 


\section{Gonadotrophin receptor binding studies}

The ability of horse CG to bind to donkey gonadal receptors was investigated initially by measuring the receptor binding activity of LH, FSH and horse CG in 3 donkey tissues (follicle, corpus luteum and testis) and comparing the results to those obtained previously (Stewart \& Allen, 1979) with rat, pig, cow and horse gonadal tissues (Table 2). As expected, the binding of FSH to luteal tissue was extremely low and this could not be accurately measured for the cow and donkey. Horse and donkey gonadal tissues showed similar gonadotrophin-binding abilities which differed markedly from those expressed by the gonadal tissues of the non-equine species. Whereas the tissues of both equine species showed receptor binding activity for pituitary FSH and LH equivalent to that of the non-equine species, the binding of horse CG to donkey and horse gonadal tissues was minimal compared to the binding of this hormone to the gonadal tissues of the non-equine species. Furthermore, it was equivalent to only $2-4 \%$ of the binding shown by pituitary LH to horse gonadal tissues and $4-7 \%$ of $\mathrm{LH}$ binding to donkey tissues. In the non-equine species in which, in general, LH binding exceeded FSH binding, horse CG and human LH bound with equal efficiency (Table 2).

Table 2. Binding, expressed as $\mu \mathrm{mol} \times 10^{-11}$ hormone bound/ $\mu \mathrm{g}$ DNA, of FSH, LH and horse CG (PMSG) to various tissues

\begin{tabular}{lccc}
\hline & \multicolumn{3}{c}{ Hormone } \\
\cline { 2 - 4 } \multicolumn{1}{c}{ Tissue } & FSH & LH & $\begin{array}{c}\text { Horse CG } \\
\text { (PMSG) }\end{array}$ \\
\hline Rat testis* & $2.76 \pm 0.50$ & $6.82 \pm 0.75$ & $7.02 \pm 1.50$ \\
Boar testis* & $6.30 \pm 1.02$ & $5.80 \pm 0.80$ & $5.51 \pm 0.15$ \\
Cow CL* & - & $9.01 \pm 1.20$ & $7.28 \pm 1.34$ \\
Horse follicle* & $2.54 \pm 0.35$ & $8.89 \pm 0.30$ & $0.15 \pm 0.05$ \\
Horse CL* & $0.96 \pm 0.09$ & $10.03 \pm 2.05$ & $0.42 \pm 0.14$ \\
Horse testis* & $2.95 \pm 0.25$ & $4.02 \pm 0.41$ & $0.13 \pm 0.04$ \\
Donkey follicle & $3.25 \pm 0.30$ & $5.20 \pm 0.59$ & $0.20 \pm 0.03$ \\
Donkey CL & - & $8.01 \pm 0.40$ & $0.56 \pm 0.10$ \\
Donkey testis & $3.02 \pm 0.49$ & $3.92 \pm 0.52$ & $0.26 \pm 0.09$ \\
\hline
\end{tabular}

Values are mean \pm s.e.m.

* Values taken from Stewart \& Allen (1979).

A second experiment was undertaken to assess further the relative gonadotrophin-binding capacities of horse and donkey gonadal tissues. For this, the ability of highly purified human and equine FSH and LH and horse CG to displace ${ }^{125}$ I-labelled human FSH and LH from donkey gonadal receptors was measured and findings were compared with those obtained using horse gonadal tissues in the previous study (Stewart \& Allen, 1979). These results, expressed as the amount of hormone required to displace $50 \%$ of the labelled hormone bound in the absence of unlabelled hormone, are compared with the equivalent figures for rat, cow, pig and horse gonadal tissues in Table 3. The low degree of binding of horse CG to both horse and donkey LH and FSH receptors is shown by the large amount of hormone required to cause $50 \%$ displacement in the equine tissues (92-890 ng) as compared to the non-equine tissues (7.3-17.8 $\mathrm{ng})$. The molecular weight of horse CG $(60000$; Gospodarowicz, 1972) is about double that of FSH and LH and conversion of the figures in Table 3 to a molar rather than weight comparison revealed that horse CG bound with approximately the same affinity as human LH and FSH to the non-equine receptors although its binding to the equine receptors remained very much lower in all cases. When the binding of horse CG was expressed as a percentage of that shown by horse LH and FSH (Table 4) horse CG bound with approximately equal affinity to both horse and donkey LH receptors but with only $3-4 \%$ of the affinity shown by equine LH. However, while the binding of horse $\mathrm{CG}$ to horse $\mathrm{FSH}$ receptors was almost negligible $(0.5 \%$ of equine 
FSH) its binding to donkey FSH receptors was about 7 times greater (3.6\%) and hence equivalent to the binding of horse CG to horse (3.0\%) and donkey (3.9\%) LH receptors.

Table 3. Displacement of ${ }^{125}$ I-labelled LH and FSH from equine and non-equine gonadal tissues

\begin{tabular}{|c|c|c|c|c|c|c|}
\hline \multirow[b]{2}{*}{ Tissue } & \multicolumn{3}{|c|}{${ }^{129}$ I-labelled LH } & \multicolumn{3}{|c|}{${ }^{125}$ I-labelled FSH } \\
\hline & $\begin{array}{c}\text { Horse } \\
\text { LH }\end{array}$ & $\begin{array}{c}\text { Human } \\
\text { LH }\end{array}$ & $\begin{array}{c}\text { Horse } \\
\text { CG } \\
\text { (PMSG) }\end{array}$ & $\begin{array}{c}\text { Horse } \\
\text { FSH }\end{array}$ & $\begin{array}{c}\text { Human } \\
\text { FSH }\end{array}$ & $\begin{array}{c}\text { Horse } \\
\text { CG } \\
\text { (PMSG) }\end{array}$ \\
\hline Rat testis* & $2 \cdot 0$ & $3 \cdot 5$ & $7 \cdot 3$ & $5 \cdot 1$ & $8 \cdot 1$ & $15 \cdot 2$ \\
\hline Cow $\mathrm{CL}^{*}$ & $2 \cdot 5$ & 3.4 & $7 \cdot 5$ & - & - & - \\
\hline Boar testis* & - & - & - & $5 \cdot 8$ & $9 \cdot 0$ & $17 \cdot 8$ \\
\hline Horse follicle* & $2 \cdot 0$ & $4 \cdot 0$ & 150 & $2 \cdot 0$ & $18 \cdot 5$ & 890 \\
\hline Horse $\mathrm{CL}^{*}$ & $2 \cdot 0$ & $3 \cdot 2$ & 113 & - & - & - \\
\hline Horse testis* & 1.5 & $2 \cdot 8$ & 110 & $1 \cdot 8$ & $12 \cdot 2$ & 680 \\
\hline Donkey follicle & 2.6 & $4 \cdot 2$ & 140 & $3 \cdot 2$ & 27.0 & 350 \\
\hline Donkey CL & 1.9 & $3 \cdot 8$ & 92 & - & - & - \\
\hline Donkey testis & $2 \cdot 1$ & $2 \cdot 3$ & 103 & $10 \cdot 5$ & $26 \cdot 0$ & 385 \\
\hline
\end{tabular}

Values are as ng unlabelled hormone required to displace $50 \%$ labelled LH or FSH.

* Values taken from Stewart \& Allen (1979).

Table 4. Binding of horse CG (PMSG) relative to horse LH and FSH on a molar basis

\begin{tabular}{|c|c|c|c|c|c|c|c|c|}
\hline & \multicolumn{4}{|c|}{ Binding to horse receptors* } & \multicolumn{4}{|c|}{ Binding to donkey receptors* } \\
\hline & \multicolumn{2}{|c|}{ LH receptors } & \multicolumn{2}{|c|}{ FSH receptors } & \multicolumn{2}{|c|}{ LH receptors } & \multicolumn{2}{|c|}{ FSH receptors } \\
\hline & $\begin{array}{c}\text { Horse } \\
\text { LH }\end{array}$ & $\begin{array}{c}\text { Horse } \\
\text { CG }\end{array}$ & $\begin{array}{l}\text { Horse } \\
\text { FSH }\end{array}$ & $\begin{array}{l}\text { Horse } \\
\text { CG }\end{array}$ & $\begin{array}{c}\text { Horse } \\
\text { LH }\end{array}$ & $\begin{array}{c}\text { Horse } \\
\text { CG }\end{array}$ & $\begin{array}{c}\text { Horse } \\
\text { FSH }\end{array}$ & $\begin{array}{c}\text { Horse } \\
\text { CG }\end{array}$ \\
\hline Follicle & 100 & $2 \cdot 7$ & 100 & 0.4 & 100 & 3.7 & 100 & 1.8 \\
\hline $\mathrm{CL}$ & 100 & $3 \cdot 5$ & - & - & 100 & $4 \cdot 1$ & - & - \\
\hline Testis & 100 & $2 \cdot 7$ & 100 & 0.6 & 100 & $4 \cdot 0$ & 100 & $5 \cdot 4$ \\
\hline Mean & $100 \%$ & $3.0 \%$ & $100 \%$ & $0.5 \%$ & $100 \%$ & $3.9 \%$ & $100 \%$ & $3.6 \%$ \\
\hline
\end{tabular}

* Figures are calculated on a molar basis relative to the binding shown by horse LH and FSH and using the data in Table 3.

\section{Discussion}

Our observations in the present study on maternal ovarian activity during pregnancy in equids support the earlier suggestion of Evans \& Irvine (1975) that it is pituitary FSH, rather than CG, which stimulates accessory follicular development. Considerable follicular growth occurs before the production of CG and, at least in horse, donkey and mule pregnancies, follicular activity is less marked during the period when CG is being secreted than earlier in gestation. Further, although a significant rise in maternal plasma progesterone concentrations occurs at Week 6 in response to the appearance of CG, there is afterwards no detectable relationship between the degree of luteal activity and the amount of gonadotrophin being secreted. For example, while CG levels in mares carrying normal horse conceptuses are 5 times greater than those in mares carrying mule conceptuses, ovarian activity, as measured by maternal plasma progestagen levels, is the same in the two types of pregnancy.

Nevertheless, it would appear that although CG does not stimulate follicular growth it 
almost certainly does cause ovulation and/or luteinization of the accessory follicles. It may also help to prolong the life-span and maintain the secretory activity of the secondary corpora lutea so formed, because in mule pregnancies, in which CG secretion ceases much earlier in gestation, ovarian progesterone production likewise begins to decline earlier than in mares carrying horse conceptuses. However, the observations of Allen (1969a) and Mitchell \& Allen (1975) that the corpora lutea often regress if the conceptus is removed from the uterus after Day 40, despite the continued presence of high CG concentrations in the blood, indicate that a factor(s) of fetal origin other than CG is involved in the maintenance of luteal function during the first half of equine pregnancy.

The excessive enlargement of the ovaries observed in donkeys carrying hinny conceptuses supports the evidence of Sheldrick et al. (1977) for an ovarian origin of the very high concentrations of blood progesterone. The total amount of luteal tissue in these animals was at least 10 times greater than that found at any stage in the other three types of pregnancy and the individual follicles and the corpora lutea were much larger (up to $6 \mathrm{~cm}$ in diameter) than those normally found in donkey ovaries $(2-3 \mathrm{~cm})$. Furthermore, the 10 -fold rise in plasma progestagen levels did not begin until Week 8-9 of gestation, suggesting that several days were required for the large follicles to develop and ovulate.

Taken together these findings strongly indicate that accessory follicular growth in donkeys carrying hinny conceptuses is directly stimulated by the CG being secreted. This is quite unlike the situation in horse, mule and normal donkey pregnancies and it would therefore seem that hinny CG, but not horse, mule or donkey CG, is able to exert its FSH-like activity on the maternal ovaries. Hinny CG expresses considerably more FSH-like activity than donkey CG and it probably consists of a mixture of horse CG (FSH:LH ratio $=1.0)$ and donkey CG (FSH : LH ratio $=0 \cdot 1)$ (Stewart et al., 1977). The ovaries of the jenny donkey would normally be exposed to very low levels of FSH-like activity when she is carrying a normal intraspecific donkey conceptus. As shown in the present study, donkey ovarian FSH receptors do have greater capacity to bind horse CG than do horse ovarian FSH receptors. Hence, when donkey ovaries are exposed to the much larger amounts of FSH-like activity expressed by hinny CG, they are able to respond and so become hyperstimulated.

From the available evidence it may be postulated that the horse has evolved a refractoriness to at least the FSH-like activity of its own chorionic gonadotrophin in order to protect its ovaries from being overstimulated during normal intraspecific pregnancy. The results of the present study indicate that a similar ovarian protective mechanism probably operates in the donkey although her ovaries are not as refractory to horse CG as are those of the horse. This has presumably arisen because donkeys are not normally exposed to horse CG during pregnancy and it is only when a hybrid hinny pregnancy is conceived, an unlikely event in nature due to the considerable differences in the patterns of courtship and mating exhibited by these two species (Klingel, 1975; Short, 1975), that the otherwise successful evolutionary adaptation breaks down.

In conclusion we would propose that equine CGs do have some luteotrophic function in equine pregnancy, being necessary to cause ovulation and/or luteinization of pituitary FSH-stimulated accessory follicles and, in concert with other fetal factors, to prolong the life-span and secretory activity of the secondary corpora lutea. However, both these gonadotrophic functions are attributable to LH-like, rather than FSH-like activity and it is still unclear why equine CG should exhibit FSH-like activity, especially when such activity is apparently not required and may, in fact, be harmful.

We are grateful to Dr Anne Stockell-Hartree, University of Cambridge, Professor H. Papkoff, Hormone Research Laboratory, San Francisco, and Dr L. E. Reichert, Emory University, Atlanta, U.S.A. for generous gifts of highly purified hormone preparations. The study was financed by the Thoroughbred Breeders' Association of Great Britain. 


\section{References}

Allen, W.R. (1969a) Factors influencing Pregnant Mare Serum Gonadotrophin production. Nature, Lond. 223, 64-66.

Allen, W.R. (1969b) The immunological measurement of Pregnant Mare Serum Gonadotrophin. J. Endocr. 43, 593-598.

Allen, W.R. (1970) Equine gonadotrophins. Ph.D. thesis, University of Cambridge.

Allen, W.R. (1975) The influence of fetal genotype upon endometrial cup development and PMSG and progestagen production in equids. J. Reprod. Fert., Suppl. 23, 405-413.

Allen, W.R. \& Moor, R.M. (1972) The origin of the equine endometrial cups. I. Production of PMSG by fetal trophoblast cells. J. Reprod. Fert. 29, 313-316.

Allen, W.R.. Hamilton, D.W. \& Moor, R.M. (1973) The origin of equine endometrial cups. II. Invasion of the endometrium by trophoblast. Anat. Rec. 177, 485-502.

Allen, W.R., Stewart, F. \& Urwin, V.E. (1980) Gonadotrophin and steroid hormone production in pregnant equids carrying intra-, inter- and extraspecific conceptuses. Proc. 6th Int. Congr. Endocrinology, Melbourne, p. 217 (Abstr.).

Amoroso, E.C., Hancock, J.L. \& Rowlands, I.W. (1948) Ovarian activity in the pregnant mare. Nature, Lond. $161,355-356$.

Bain, A.M. (1967) The ovaries of the mare during early pregnancy. Vet. Rec. 80, 229-231.

Bangham, D.R. \& Woodward, P.M. (1966) The Second International Standard for Serum Gonadotrophin. Bull. Wld Health Org. 35, 761-773.

Bassett, J.M. \& Hinks, N.T. (1969) Micro-determination of corticosteroids in ovine peripheral plasma: effects of venipuncture, corticotrophin, insulin and glucose. J. Endocr. 44, 387-403.

Burton, K. (1956) A study of the conditions and mechanism of the diphenylamine reaction for the colorimetric estimation of deoxyribonucleic acid. Biochem. J. 62, 315-323.

Calisti, V. \& Oliva, O. (1956) La reazione di Friedman nella cavalla e vell'asina gravide per accoppiamento interspecifico. Atti Soc. ital. Sci. Vet. 10, 249-251.

Cheng, K.W. (1975) A radioreceptor assay for folliclestimulating hormone. J. clin. Endocr. Metab. 41, 581-589.

Cole, H.H. (1936) On the biological properties of mare gonadotropic hormone. Am. J. Anat. 59, 299-332.

Evans, M.J. \& Irvine, C.H.G. (1975) The serum concentrations of $\mathrm{FSH}, \mathrm{LH}$ and progesterone in the oestrous cycle and early pregnancy in the mare. J. Reprod. Fert., Suppl. 23, 193-200.

Gospodarowicz, D. (1972) Purification and physicochemical properties of the Pregnant Mare Serum Gonadotropin (PMSG). Endocrinology 91, 101-106.

Holtan, D.W., Squires, E.L., Lapin, D.R. \& Ginther, O.J. (1979) Effect of ovariectomy on pregnancy in mares. J. Reprod. Fert., Suppl. 27, 457-463.

Johansson, E.D.B. (1970) A simplified procedure for the assay of progesterone. In: Steroid Assay by Protein Binding. Acta endocr., Copenh., Suppl. 147, 188200.
King, J.M. (1965) Comparative aspects of reproduction in Equidae. Ph.D. thesis, University of Cambridge.

Klingel, H. (1975) Social organization and reproduction in equids. J. Reprod. Fert., Suppl. 23, 7-11.

Licht, P., Bona Gallo, A., Aggarwal, B.B., Farmer, S.W., Castelino, J.B. \& Papkoff, H. (1979) Biological and binding activities of equine pituitary gonadotrophins and Pregnant Mare Serum Gonadotrophin. J. Endocr. 83, 311-322.

Mitchell, D. \& Allen, W.R. (1975) Observations on reproductive performance in the yearling mare. $J$. Reprod. Fert., Suppl. 23, 531-536.

Papk off, H. (1974) Chemical and biological properties of the subunits of Pregnant Mare Serum Gonadotropin. Biochem. Biophys. Res. Commun. 58, 397404.

Reichert, L.E. (1972) Human FSH: purification, properties and some structure function relationships. In Gonadotropins, pp. 107-119. Eds B. B. Saxena, C. B. Belling \& A. M. Gandy. Wiley-Interscience, New York.

Schams, D. \& Papkoff, H. (1972) Chemical and immunochemical studies on Pregnant Mare Serum Gonadotropin. Biochim. Biophys. Acta 263, 139148.

Sheldrick, E.L., Wright, P.J., Allen, W.R. \& Heap, R.B. (1977) Metabolic clearance rate, production rate, and source of progesterone in donkeys with fetuses of different genotypes. J. Reprod. Fert. 51, 473-476.

Short, R.V. (1959) Progesterone in blood. IV. Progesterone in the blood of mares. J. Endocr. 19, 207-210.

Short, R.V. (1975) The contribution of the mule to scientific thought. J. Reprod. Fert., Suppl. 23, 359-364.

Squires, E.L. \& Ginther, O.J. (1975) Follicular and luteal development in pregnant mares. J. Reprod. Fert., Suppl. 23, 429-433.

Stewart, F. (1978) Equine Chorionic Gonadotrophins. $\mathrm{Ph}$.D. thesis, University of Cambridge.

Stewart, F. \& Allen W.R. (1979) The binding of FSH, LH and PMSG to equine gonadal tissues. J. Reprod. Fert., Suppl. 27, 431-440.

Stewart, F., Allen, W.R. \& Moor, R.M. (1976) Pregnant Mare Serum Gonadotrophin: ratio of folliclestimulating hormone and luteinizing hormone activities measured by radioreceptor assay. J. Endocr. 71, 371-382.

Stewart, F., Allen, W.R. \& Moor, R.M. (1977) Influence of foetal genotype on the follicle-stimulating hormone: luteinizing hormone ratio of Pregnant Mare Serum Gonadotrophin. J. Endocr. 73, 419-425.

Stockell-Hartree, A. (1966) Separation and partial purification of the protein hormones from human pituitary glands. Biochem. J. 100, 754-761.

van Niekerk, C.H. (1973) Morphological and physiological changes in the genital system of mares. D.V.Sc. thesis, University of Pretoria.

van Rensburg, S.J. \& van Niekerk, C.H. (1968) Ovarian function, follicular oestradiol-17 $\beta$ and luteal progesterone and $20 \alpha$-hydroxy-pregn-4-en-3-one in cycling and pregnant equines. Onderstepoort J. vet. Res. 35, 301-318. 